\title{
Muğla ili Menteşe yöresi orman yangını risk potansiyeli haritasının coğrafi bilgi sistemleri ile belirlenmesi
}

\author{
Mehmet Hanifi Alkayış $^{1 *}$, Asena Karslığlu ${ }^{2}$, , Mehmet İnanç Onur ${ }^{\circledR}$ \\ ${ }^{1}$ Eskişehir Teknik Üniversitesi, Fen Bilimleri Enstitüsü, Inşaat Mühendisliği Bölümü, Isparta, Türkiye \\ ${ }^{2}$ Eskisehir Teknik Üniversitesi, Mühendislik Fakültesi, İnşaat Mühendisliği Bölümü, Eskişehir, Türkiye
}

\author{
Anahtar Kelimeler \\ Doğal Afetler \\ Orman Yanginı \\ CBS \\ Yangın Risk Haritası
}

\begin{abstract}
ÖZ
Orman yangınları, farklı sebeplerle bașlayıp geniş alanlara yayılabilen büyük bir çevre felaketidir. Ülkemizde Akdeniz ve Ege bölgeleri, bașta olmak üzere yaklașık 12 milyon hektar ormanlık alan yangın konusunda potansiyel risk taşımaktadır. Orman yangını risk bölgeleri, yangının kolayca başlayabileceği ve diğer alanlara hızlıca yayılabileceği yerler olarak bilinmektedir. Doğayı kontrol etmek imkânsızdır, fakat orman yangını risk bölgelerini haritalayarak yangın yayılımını en aza indirmek ve hasarı azaltmak mümkündür. Orman Genel Müdürlügü'nün 2018 yılı verilerine göre ülkemizde toplam 2167 adet orman yangını olduğu ve 299 adet orman yangınıyla Muğla ilinin 1.sırada olduğu görülmektedir. Menteșe, Kavaklıdere, Ula, Yatağan, Milas, Marmaris, Datça ve Bodrum ilçelerini kapsayan Menteșe yöresinde ise bu yangınların yaklaşık yarısı gerçekleşmiştir. Bu çalışmanın amacı Muğla ili Menteșe yöresinin yangın risk haritasının hazırlanmasıdır. Çalışma için yola ve yerleşime olan uzaklık, bakı, eğim ve vejetasyon temel parametreler olarak belirlenmiştir. Çalıșma sonucunda Coğrafi Bilgi Sistemleri (CBS) tabanlı orman yangını risk haritası hazırlanmıştır. Yangın risk haritasına göre; alanın \%11,86'sı yüksek riskli, \%18,32'si riskli, \%25,23'ü orta riskli, \%20,40'1 düşük riskli, \%24,19'u ise risksizdir. Çalışma sonuçlarının orman yangınlarına karşı planlama, tedbir ve yönetim çalışmalarında yol gösterici olacağı düşünülmektedir.
\end{abstract}

\section{Determination of forest fires risk potential map of Menteșe region of Muğla with geographic information systems}

\section{Keywords}

Natural disasters

Forest fires

GIS

Fire risk analysis

\begin{abstract}
Forest fires are a major environmental disaster, they can start from different reasons and spread over large areas. In our country, approximately 12 million hectares of forest area, especially Mediterranean and Aegean regions have a potential risk for fire. Forest fire risk zones are known as places where the fire can easily start and spread quickly to other areas. It is impossible to control nature, but it is possible to minimize fire spread and reduce damage by mapping forest fire risk areas. According to the 2018 data of the General Directorate of Forestry, it is seen that there are 2167 forest fires in our country and Muğla province is the first with 299 forest fires. Approximately half of these fires occurred in Menteșe, which includes Menteșe, Kavaklıdere, Ula, Yatağan, Milas, Marmaris, Datça and Bodrum districts. The aim of this study is to prepare the fire risk map of Menteşe region in Muğla province. Distance, aspect, slope and vegetation are determined as the main parameters for the study. As a result of the study, a forest fire risk map has been prepared based geographical information systems (GIS). According to the fire risk map, $11.86 \%$ of the area has high risk, $18.32 \%$ risk, $25.23 \%$ intermediate risk, $20.40 \%$ low risk and $24.19 \%$ non-risk. It is thought that the results of the study will be a guide in planning, precaution and management works against forest fires.
\end{abstract}




\section{GíRiş}

Dünya nüfusunun sürekli artışı ormanlık alanların azalmasının başlıca sebeplerindendir. Nüfus artışı insanların yerleşme, sanayileşme, turizm gibi çeșitli ihtiyaçlarını doğurmakta ve kentleșme ile birlikte ormanlar yok edilmektedir. Ayrıca, mevcut ormanların büyük bir kısmının zarar görmesine orman yangınları sebep olmaktadır. Dünyada, 2019 yılında 12 milyon hektar ormanın yangın nedeniyle yok olduğu belirlenmiștir (WRI, 2019). Ülkemizde Kahramanmaras ilimizden bașlayarak Akdeniz ve Ege bölgelerinin sahil bandında bulunan yaklaşık 12 milyon hektarlık orman bölgesi yangın konusunda en hassas ve riskli bölgelerdir. Özellikle yazın kurak iklim șartları itibariyle Akdeniz ve Ege bölgelerinde meydana gelen yangınlarda geniş alanlar tahrip olmaktadır. Ege'nin güneyinde ve Akdeniz'in batısında yer almasından dolayı Muğla ili yangin potansiyeli olarak, tehlike arz etmektedir.

Türkiye'de orman yangınlarının çoğunun nedeni insan faaliyetleridir. Yerleșim ve tarım alanı oluşturmak için bilinçli çıkarılan yangınların yanında, ihmalkârlık da yangın oluşum sebeplerindendir. Ülkemizde 2008-2018 yılları arasında 23.602 adet orman yangınında 84.403 hektar alanın zarar gördüğü raporlanmıştır (URL-2 2019). Orman Genel Müdürlüğü'nün 2018 yilında illere göre yayınladığı orman yangınlarının dağılımına bakıldığında toplam 2167 adet orman yangını gerçekleştiği ve 299 adet orman yangınıyla Muğla'nın 1.sırada olduğu görülmektedir. Yaklaşık 150,96 hektar alan yanmıştır. $\mathrm{Bu}$ çalışmaya konu olan Menteşe yöresinde (Menteșe, Kavaklıdere, Ula, Yatağan, Milas, Marmaris, Datça ve Bodrum ilçeleri) ise 2018 yılında 134 adet orman yangını görülmüştür. Bu yangınlar sonucu 80,15 hektar ormanlık alan yok olmuștur. Şekil 1'de 2009-2018 yılları arasında orman yangınlarının yıllık ortalama sayılarının sırası ile en çok Milas, Menteșe ve Marmaris ilçelerinde olduğu görülmektedir. Șekil 2'de ise yllı ortalama yanan alan miktarları Milas 116,2 hektar, Menteșe (Muğla Merkez) 36,1 hektar ve Marmaris 32,5 hektar șeklinde verilmiştir (URL-3 2018).

Uydu verileri, orman yangınlarının ve riskli alanların haritalanmasında önemli bir rol oynamaktadır (Jaiswal vd. 2001). Günümüzde, Coğrafi Bilgi Sistemleri (CBS) ile orman yangını risk haritası hazırlama çalışmaları hız kazanmıștır (Sharma vd. 2009). CBS, doğal afetlerin ön tahmini ve modellenmesi, afet anındaki tedbirlerin planlanması, afet sonrası hasar tespiti analizlerini yüksek doğrulukta yapabilmesi, hızı ve ekonomikliği nedeniyle tercih edilmektedir (Erten vd. 2005). CBS, yangının modellenmesinde yayılımı etkileyen coğrafi etmenler olan eğim, bakı, yol ve yerleşim uzaklığını da analize dâhil etmektedir. $\mathrm{Bu}$ yüzden $\mathrm{CBS}$ orman yangını risk analizlerinde etkin bir uygulamadır.

Orman yangınlarının geniş alanlara yayılımını azaltma tedbirleri kapsamında riskli alan modelleri ve haritalama çalışmalarının gerekliliği açıktır. Coğrafi bilgi sistemlerini kullanarak yangın risk haritasının hazırlanması, orman yangın yönetiminin de önemli bir kısmını oluşturmaktadır. Bu çalışmada, 2018 yılında Türkiye'de en çok orman yangınının görüldüğü MuğlaMenteșe yöresi için orman yangını risk haritası CBS ortamında hazırlanmıştır. Bu harita ile orman yangını yayılımına karşı önleme faaliyetleri bölge bazında farklılaştırılabilecektir. Böylece daha etkili yönetim modelleri uygulanabileceği gibi optimum kaynak kullanımı vb. ekonomik faydalar da elde edilebilecektir.

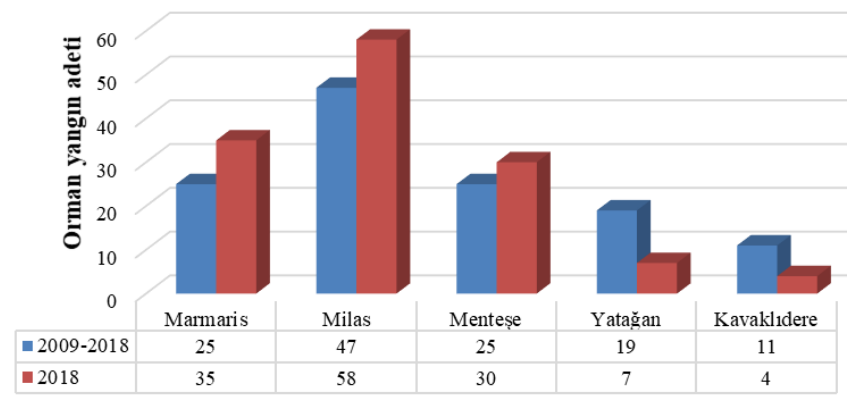

Şekil 1. Menteşe yöresi 2009-2018 yılları yangın sayısı yıllık ortalaması ve 2018 yılı yangın sayısı (URL-3 2018)

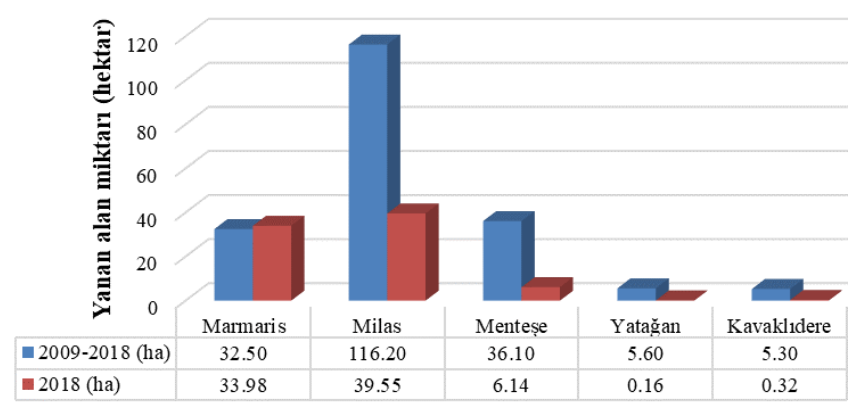

Şekil 2. Menteşe yöresi 2009-2018 yılları yanan alanın yıllık ortalaması ve 2018 yılı yanan alan (URL-3 2018)

\section{2. ÇALIŞMA ALANI}

Araştırma alanı Muğla-Menteşe yöresidir. Muğla ilinin yüzölçümü $12890 \mathrm{~km}^{2}$ dir. Şekil 3'de belirtildiği gibi Ege Bölgesi'ndedir fakat topraklarının küçük bir kısmı Akdeniz Bölgesi sınırları içerisine girmektedir. Menteșe yöresi ise Muğla ilinin Menteșe, Kavaklıdere, Ula, Yatağan, Milas, Marmaris, Datça ve Bodrum ilçelerini kapsamaktadır. $36^{\circ} 17^{\prime}$ ve $37^{\circ} 33^{\prime}$ kuzey enlemleri ile $27^{\circ} 13^{\prime}$ ve $29^{\circ} 46^{\prime}$ doğu boylamları arasında bulunmaktadır.

Menteşe yöresinde Akdeniz iklimi görülmekte olup, dağlık bir coğrafi yapıdan oluşmaktadır. Muğla ilinin 1928-2019 yılları içindeki ekstrem sıcaklık değerleri $+47.0^{\circ} \mathrm{C}$ ile $-13.0^{\circ} \mathrm{C}$ olarak kaydedilmiștir. Ortalama yıllık sıcakllk değerleri ise $+15.0^{\circ} \mathrm{C}$ ile $+25.0^{\circ} \mathrm{C}$ 'dir. Ylllık ortalama bağıl nem $\% 65$ civarındadır. Yıllık toplam yağıș miktarı ise metrekareye $1200 \mathrm{~mm}$ ile $670 \mathrm{~mm}$ arasında değişmektedir. Fakat yağışların çoğunlukla kış mevsiminde olması nedeniyle yaz aylarında kuraklık belirgindir (URL-1 2018).

Muğla ilindeki ormanlık alan Türkiye ortalamasının oldukça üstündedir. Muğla ilinin genelinin $\%$ 68'i, Menteșe yöresinin ise \% 66'sı ormanlık alandır. Muğla ilinde 2018 yllında gerçekleșen 3 büyük yangının ikisi Marmaris ve Milas ilçelerinde meydana gelmiştir (URL-3 2018). 


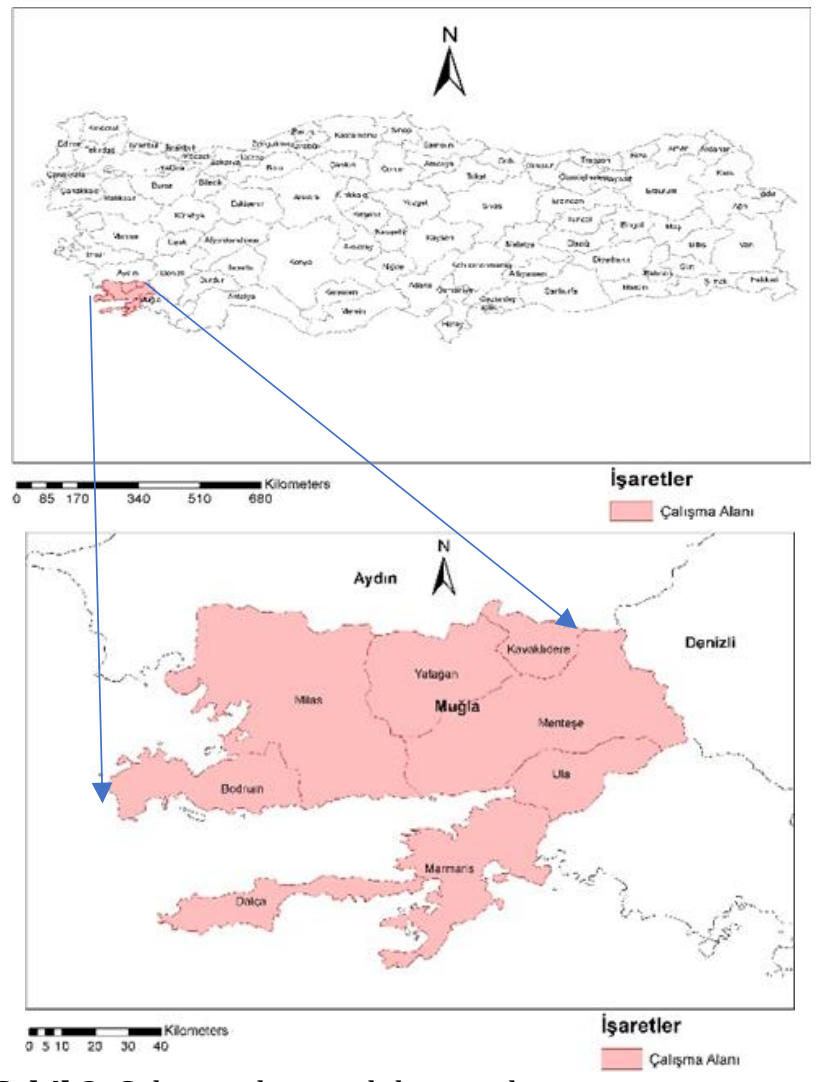

Şekil 3. Çalışma alanının lokasyon haritası

\section{MATERYAL ve YÖNTEM}

$\mathrm{Bu}$ çalışmada, CBS teknikleri kullanılarak Muğla ili Menteşe yöresinin orman yangını potansiyel risk haritasının hazırlanması amaçlanmıştır. 1/25000 ölçekli topografya verilerinden Sayısal Yükseklik Modeli (SYM), eğim ve bakı haritaları üretilmiştir. Vejetasyon türlerine ait veriler ise Muğla Orman Bölge Müdürlüğüne ait meșcere haritalarından elde edilmiştir. Harita Genel Müdürlügü Atlas Küre uygulamasında yol ve yerleșim yerleri çizilerek ArcGIS programında vektör verileri oluşturulmuştur. CBS ortamında nem, sıcaklık ve topografya analizlerinden "layer" veri yapısı oluşturulmuştur. Daha sonra layer verileri raster veriye dönüştürülerek RGB formunda risk alanları elde edilmiștir. Verilerin analizi, modellenmesi ve sonuç haritalarının elde edilmesi için ArcGIS 10.7 programı kullanılmıştır. Çalışma süreci Erten vd. 2005 ile Asri vd. 2015 tarafından önerilen yöntemler sentezlenerek oluşturulmuş, iş-akış diyagramı Şekil 4'te verilmiştir.

Yola ve yerleşime mesafe yangının çıkışını etkilerken, eğim, bakı ve bitki örtüsü ise yangının yayılmasını etkilemektedir. Öncelikle, bütün değişkenlerin yangına sebep olmasına ve yayılmasına göre risk faktör değerleri tayin edilmiştir. Yangın için çok riskli olan koşul "5", risksiz olan koşul ise "1" ile ifade edilmektedir. Ormanlık alandaki coğrafi değişkenlere, CBS ortamında yeniden sınıflandırma (Reclassify) modülü kullanılarak atanan etki faktörleri Tablo 1'de verilmiştir. Değer atamasından sonra Katman analizi (Overlay Analysis) yapılarak orman risk haritası oluşturulmuştur. Yangın risk düzeyi belirlenirken Erten vd. (2005) ve Joaquim vd. (2007) tarafından kullanılmış denklem 1 referans alınmıștır.
Tablo 1. Değişkenler ve faktör ağırlıkları (Erten vd. 2005; Joaquim vd. 2007)

\begin{tabular}{|c|c|c|c|c|}
\hline Değişkenler & Ağırlık & Sinif & Faktör & Risk Sınıfı \\
\hline \multirow{5}{*}{$\begin{array}{c}\text { Bitki } \\
\text { Örtüsü } \\
\text { (FT) }\end{array}$} & \multirow{5}{*}{7} & Çok Kuru & 5 & Çok Riskli \\
\hline & & Kuru & 4 & Riskli \\
\hline & & $\begin{array}{l}\text { Orta } \\
\text { Nemli }\end{array}$ & 3 & Orta Riskli \\
\hline & & Nemli & 2 & Düșük Riskli \\
\hline & & $\begin{array}{c}\text { Çok } \\
\text { Nemli }\end{array}$ & 1 & Risksiz \\
\hline \multirow{5}{*}{$\begin{array}{l}\text { Eğim } \\
(\mathrm{S}) \\
(0)\end{array}$} & \multirow{5}{*}{5} & $>30$ & 5 & Çok Riskli \\
\hline & & $20-30$ & 4 & Riskli \\
\hline & & $10-20$ & 3 & Orta Riskli \\
\hline & & $5-10$ & 2 & Düşük Riskli \\
\hline & & $0-5$ & 1 & Risksiz \\
\hline \multirow{5}{*}{$\begin{array}{c}\text { Bakl } \\
\text { (A) }\end{array}$} & \multirow{5}{*}{5} & Güney & 5 & Çok Riskli \\
\hline & & Batı & 4 & Riskli \\
\hline & & Doğu & 3 & Orta Riskli \\
\hline & & Kuzey & 2 & Düşük Riskli \\
\hline & & Düz & 1 & Risksiz \\
\hline \multirow{5}{*}{$\begin{array}{l}\text { Yola Mesafe } \\
\text { (DR) } \\
\text { (m) }\end{array}$} & \multirow{5}{*}{3} & $0-100$ & 5 & Çok Riskli \\
\hline & & $100-200$ & 4 & Riskli \\
\hline & & $200-300$ & 3 & Orta Riskli \\
\hline & & $300-400$ & 2 & Düşük Riskli \\
\hline & & $>400$ & 1 & Risksiz \\
\hline \multirow{5}{*}{$\begin{array}{l}\text { Yerlessmeye } \\
\text { Mesafe } \\
\text { (DS) } \\
\text { (m) }\end{array}$} & \multirow{5}{*}{3} & $0-500$ & 5 & Çok Riskli \\
\hline & & $500-1000$ & 4 & Riskli \\
\hline & & $\begin{array}{l}1000- \\
1500\end{array}$ & 3 & Orta Riskli \\
\hline & & $\begin{array}{l}1500- \\
2000\end{array}$ & 2 & Düşük Riskli \\
\hline & & $>2000$ & 1 & Risksiz \\
\hline
\end{tabular}

$\mathrm{RS}=7 * \mathrm{FT}+5 *(\mathrm{~S}+\mathrm{A})+3 *(\mathrm{DR}+\mathrm{DS})$

RS = Yangın risk düzeyi

FT = Bitki örtüsünün nem durumuna göre yanabilme potansiyeli

$\mathrm{S}=$ Eğim

$\mathrm{A}=\mathrm{Bakl}$

$\mathrm{DR}=$ Yola olan uzaklık

DS = Yerleşime olan uzaklık.

$\mathrm{Bu}$ denklemde RS yangın risk bölgelerini, yüksek riskli, riskli, orta riskli, düşük riskli ve risksiz olmak üzere beș sınıfta ifade etmektedir. FT, 5 sınıftan oluşan orman türlerini göstermektedir. Bunlar çok kuru, kuru, orta nemli, nemli ve çok nemli yanma potansiyeli sınıflarına ayrılan bitki örtüsüdür. Yangının yayılımına aynı derecede etkisi olan $S$ ve A parametreleri ise eğim ve bakı analizlerini göstermektedir. İnsan unsurunu yangın risk modeline dâhil eden yola ve yerleșime olan uzaklık parametreleri de DR ve DS ile isimlendirilmiştir. 


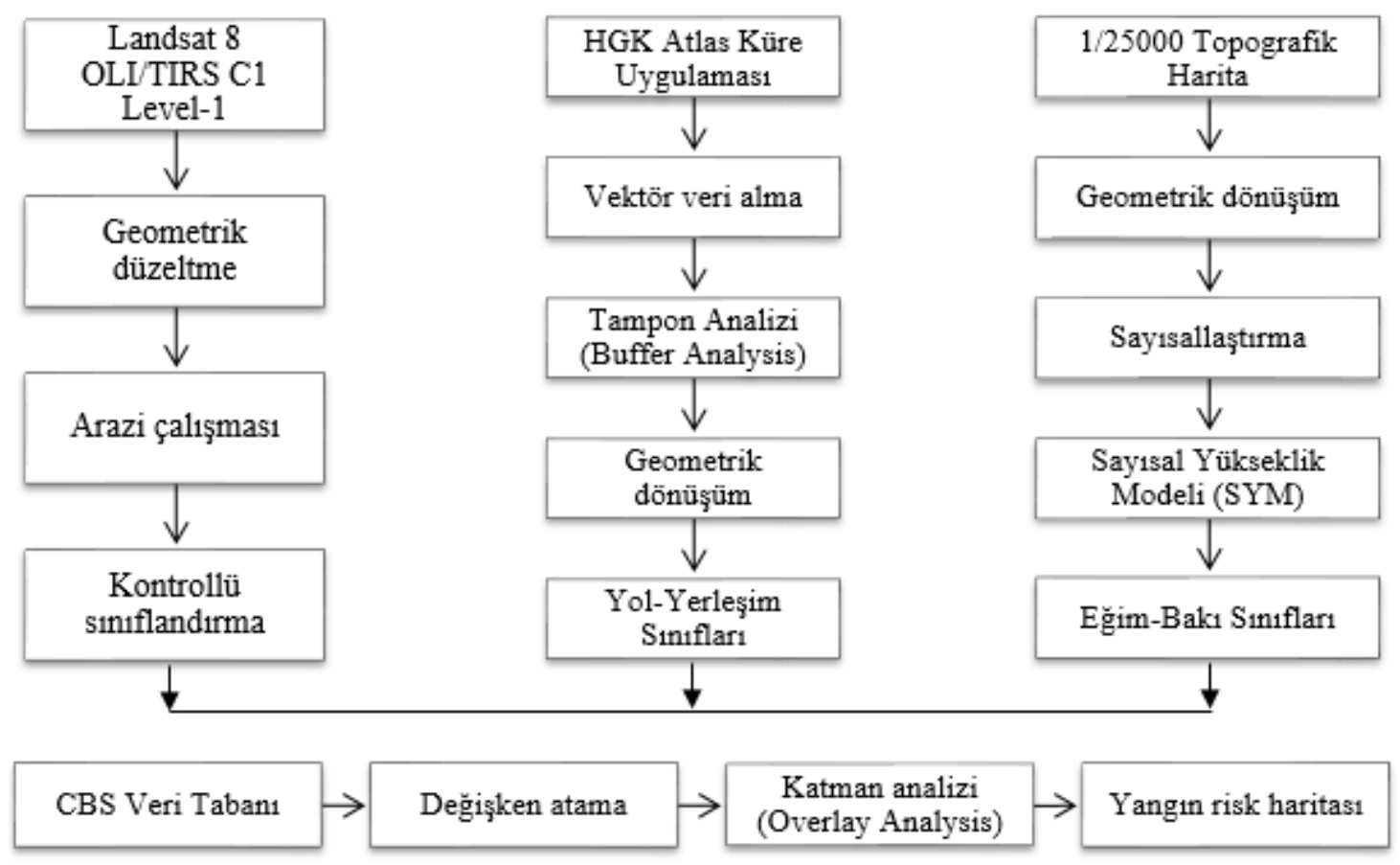

Şekil 4. Orman yangını risk haritası akış diyagramı

Orman yangınını etkileyen faktörlere ilișkin bu giriș bilgileri, bir bölgedeki yangın riskinin ağırlıklarını göstermektedir. Faktörler önem sırasına göre bitki tipi, eğim, bakı, yollardan ve yerleşimlerden uzaklık şeklinde analiz edilmiştir. Her sınıfın farklı ağırlıkları vardır. Bitki türleri orman yangınlarının patlak vermede etkisi olan nem bağlamına göre sınıflandırılmıştır. Örneğin, çok kuru bitki türü en yanıcı ise orta nemli bitki türü yanıcıdır. Yangının eğim etkisi davranıșı en yüksek ikinci ağırlık olarak değerlendirilmiştir. Yangın en hızlı yüksek eğimli yamaçlarda ve en az düşük eğimli yamaçlarda hareket etmektedir. Eğim sınıfları bu kurala göre oluşturulmuştur. Bakı ile eğime eşit ağırlık atanmıştır. Güneş ışığı güneydeki yamaçlarda çok daha fazla yansıdığı için, yangın hızlı bir şekilde patlak vererek güney taraflarına yayılmaktadır. Yol ve yerleşim yerlerinden uzaklık üçüncü en yüksek ağırlık olarak değerlendirilmiștir. Su kütle alanları ise orman yangını riskini etkilememektedir. $\mathrm{Bu}$ bölgelerin yangın derecelendirme sınıfının belirlenmesinde ağırlıkları yoktur.

Yapılan çalışmada kullanılan referans denklemi literatürde kullanılan denklemlerden biridir ve çalıșma alanındaki faktörlerin ağırlı̆̆ına göre değişmektedir. Çalışma alanımız Akdeniz Bölgesi bitki türlerinin hakim olduğu, topografik yapısında çoğunlukla eğimli bölgelerin ve güney bakının ağırlıkta olduğu bir alan olmasına rağmen insan faktörü etkisinin bu faktörlere göre daha az olduğu bir alandır. Bu sebeple literatür ile karşılaştırma yapıldığında (Karabulut, 2013 ve Bingöl, 2017) bu değerlendirme yönteminin çalıșma alanımız için kullanımı uygun görülmüştür.

\section{1. Çalışma Alanında Risk Faktörlerinin Değerlendirilmesi}

Akdeniz Bölgesinin coğrafyası, iklimi ve bitki örtüsü gibi özellikleri orman yangınları ile yakın iliş̧i içerisindedir (Sharples vd. 2009). Bölgedeki topoğrafik yapının güney ve batı bakılarda olması, eğimin yüksek olması ve zirve ile vadilerdeki ısınma derecelerinin farkı, yangının yayılış hızının artmasında olası etkiye sahiptir (Eron 1988).

\subsubsection{Bitki örtüsü}

Muğla ilinde 2000 metre yükseltilere kadar ağırlıklı olarak kızılçam (Pinus brutia), karaçam (Pinus nigra), meşe (Quercus) ve ardıç (Juniperus) karışımı türlerden oluşan ormanlar yer alırken, daha yüksek kesimlerde çayırlara rastlanmaktadır. 2200 metreden sonra açılılık alanlar bulunmaktadır. Muğla'da, yerleşim alanları oluşturmak için kızılçam ormanlarının tahribe uğradığı, yerlerine ise maki vejetasyonun geliştiği görülmektedir (Türkeş vd. 2013).

Bitki örtüsü orman yangınlarının ilerlemesine sebep olan ve davranışlarını etkileyen en önemli faktörlerden biridir. Örneğin karaçam gibi iğne yapraklı ve kuru karakterdeki türler yangın için uygun koşulları oluşturmakta, kayın (Fagus) gibi geniş yapraklı ve nemli türler ise yangının yayılımını engelleyici özellik göstermektedir (Akkaş vd. 2008, Karabulut vd. 2013).

Vejetasyon risk haritası oluşturulurken öncelikle kontrollü sınıflandırma yapılmıştır. Kontrollü sınıflandırmada meşcere haritalarından alınan veriler ile Gauss Maksimum olabilirlik yöntemi kullanılmıştır. $\mathrm{Bu}$ yöntem geleneksel bir görüntü sınıflandırma tekniğidir. $\mathrm{Bu}$ teknik birbirine en fazla benzerlik gösteren, normal dağılımlı pikseller üzerinde sınıflandırma gerçekleștirir. Algoritma, her sınıf için bir pikselin olasılık işlevini inceleyen ve pikseli en yüksek olasılıkla sinıfa atayan istatistiksel bir karar kuralına dayanmaktadır.

Muğla ili Menteşe yöresindeki vejetasyon türleri nemlilik derecelerine göre sınıflandırılmıştır. Çalışma alanındaki çam türleri "Çok kuru", sedir türleri "Kuru", meșe türleri "Orta nemli", ardıç türleri "Nemli", Servi ve sığla türleri ise "Çok nemli" sınıfında konumlandırılmıştır (Bingöl 2017). 


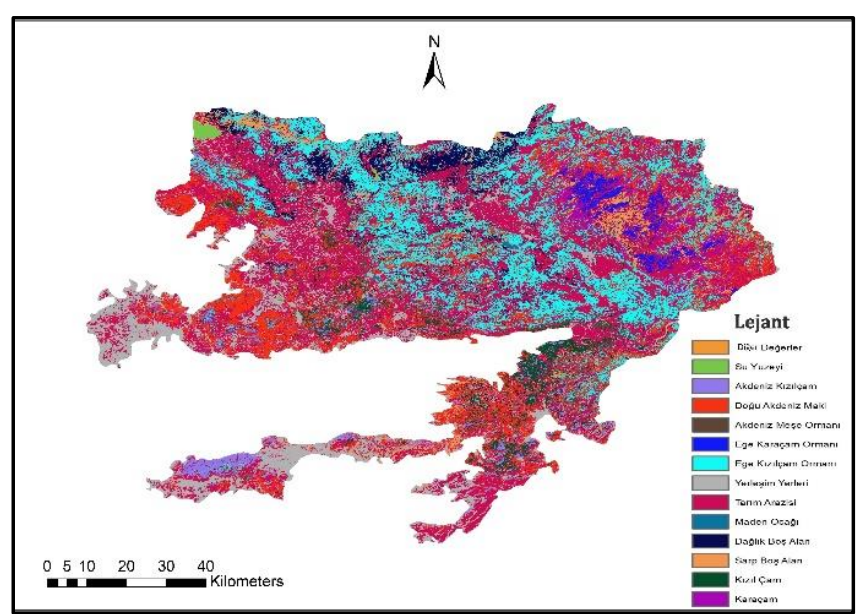

Şekil 5. Vejetasyon türleri haritası

Şekil 5'de su alanları risksiz, orman bulunmayan veya az bulunan dağllk bölgeler, tarım arazileri ile yerleşim yerleri düşük riskli olarak belirlenmiştir.

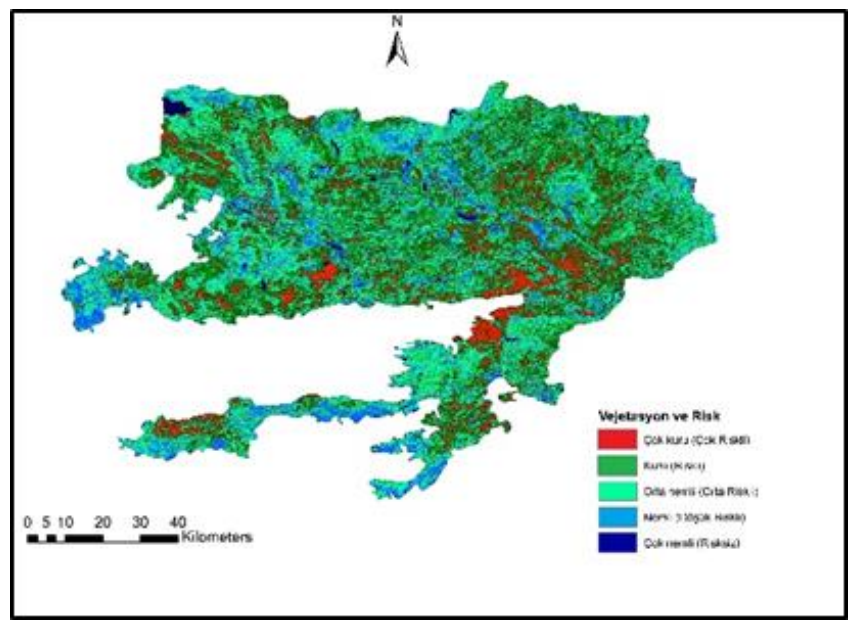

Şekil 6. Vejetasyon türleri risk sınıflandırma haritası

Sonuç olarak Şekil 6'da belirtildiği gibi nemlilik derecelerine göre risk sınıflandırılması yapılmıştır.

\subsubsection{Topografya}

Muğla ilinin özellikle kuzey, kuzeybatı kesimini oluşturan Menteşe yöresinde; dağların denize paralel uzanması sebebiyle oluşan engebeli yeryüzü şekli, bölgeyi Ege'nin diğer kıyı șehirlerinden ayıran önemli bir etkendir (URL-3 2018). Topografik koşullar orman yangın davranışının şekillenmesinde etkili fiziksel faktörler arasındadır. Eğim, bakı ve yükseklik birçok çalıșmada ana topografik faktörler olarak kabul edilmektedir (Akbulak vd. 2018). Eğim ve bakl, ormanın güneş alma ve nem koşullarını doğrudan etkilemektedir.

Şekil 7'de eğim risk haritası verilmiştir. Arazi eğiminin fazla olduğu bölgelerde yangın daha hızlı, az olduğu yerlerde ise daha yavaş yayıldığı bilinmektedir. Çalışma alanının eğiminin $\% 5$ 'ten büyük olan kısmı \%71,3 olarak belirlenmiștir.

Şekil 8 'de bakı risk haritası verilmiştir. Kuzey yarım kürede güneyi gören yamaçlarda güneşin hissedilme yüzdesi kuzeye bakan yamaçlara göre bakıdan kaynaklı daha fazladır. Çalışma alanının güneyi gören yamaçları $\% 26,3$ olarak belirlenmiştir ve yüksek risk grubundadır.

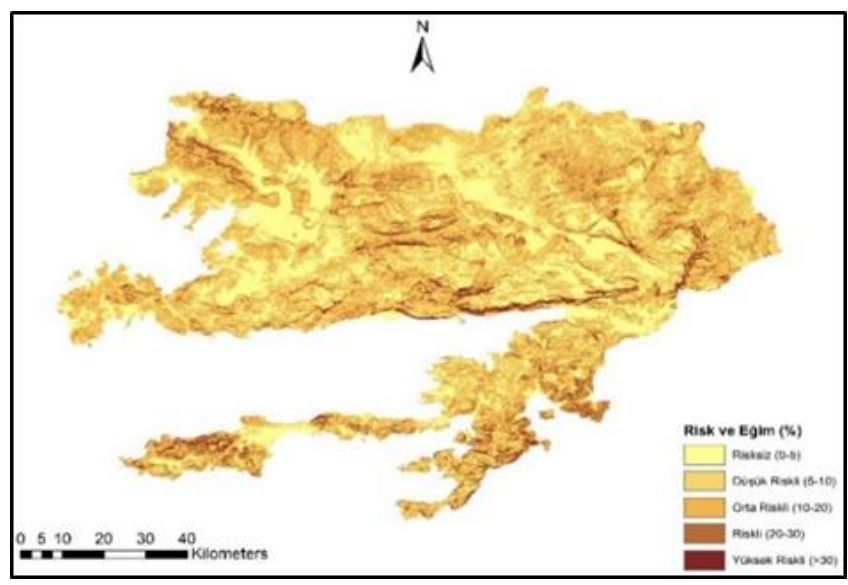

Şekil 7. Eğim risk sınıflandırma haritası

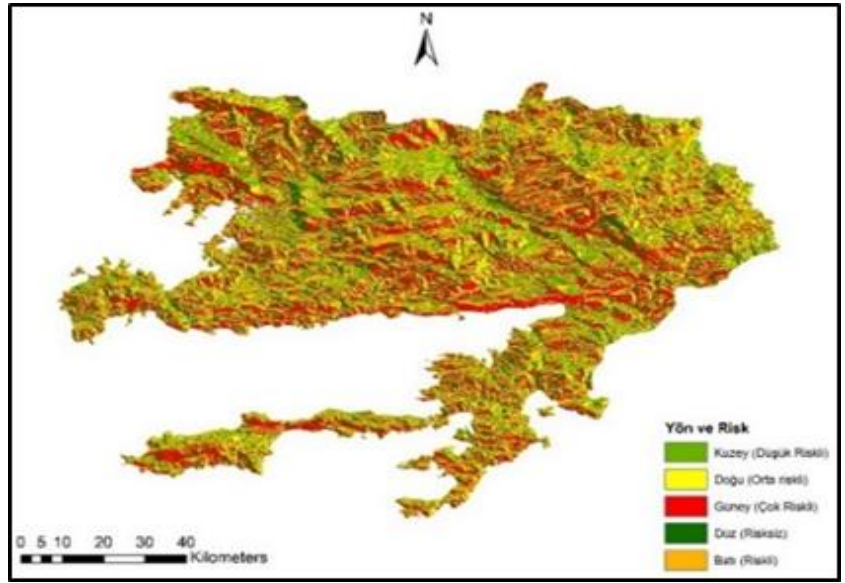

Şekil 8. Bakı risk sınıflandırma haritası

\subsubsection{Yola ve yerleșmeye olan mesafe}

Çalışma alanında 8 ilçe ve birçok yerleşim yeri mevcuttur. Orman yangını oluşumlarını etkileyen antropojenik faktörlerden olan yollara ve yerleşim yerlerine yakınlık önemli değişkenlerdendir (AvilaFlores vd. 2010). Bunun nedeni yollar ve yerleșim yerlerinin yakınındaki insanların ormanlık alanlara girmesinin kolay olması ve bu durumda ihmalkârlık veya kaza nedeniyle yangınların kolayca oluşabilmesidir. Yerleşim yerlerine olan mesafe arttıkça risk seviyesi azalmaktadır (Karabulut vd. 2013). Orman yangınlarının yayılımının önlenmesi açısından köy ve orman yolları kritik öneme sahiptir.

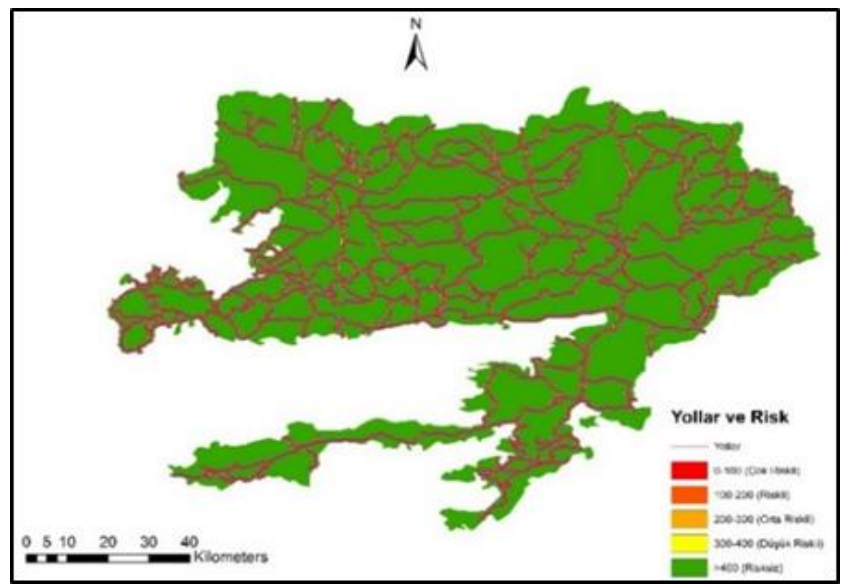

Şekil 9. Yollara olan uzaklık risk haritası 
Çalışma alanının asfalt ve köy yol güzergâhları olan mesafe sınıflandırması Şekil 9'da gösterilmektedir. Yapılan tampon analizi sonucunda arazinin \%77'si yola uzaklıktan etkilenmemektedir. Arazinin yol güzergâhlarına uzaklı̆̆ı 400 m'den küçük olan kısmı \%23 olarak belirlenmiștir.

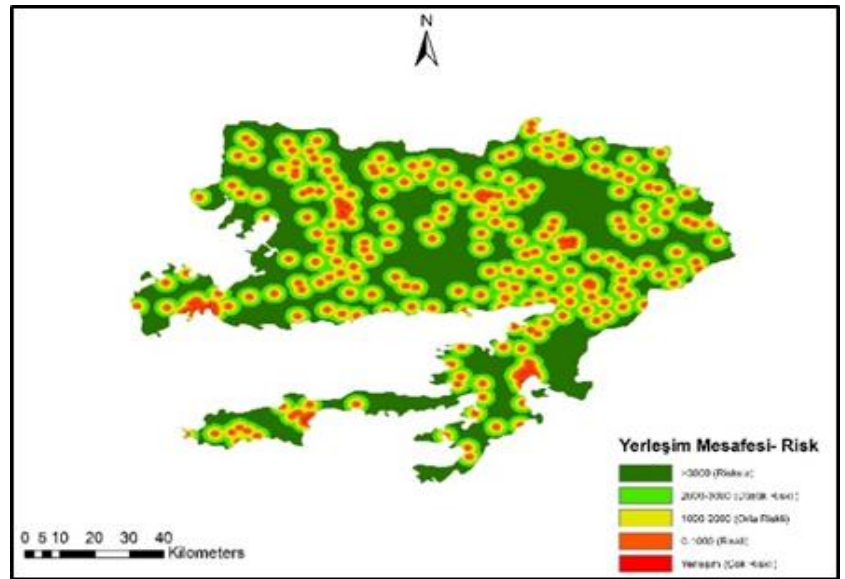

Şekil 10. Yerleşimlere olan uzaklık risk haritası

Çalışma alanının yerleşim yerlerine olan mesafe sınıflandırması Şekil 10‘da gösterilmektedir. Arazinin yerleşimlere olan uzaklığı 2000 m'den büyük olan kısmı \%39,8 olarak belirlenmiștir.

\section{BULGULAR}

Tüm değişkenlere göre risk oranları Tablo 2'de yer almaktadır. Vejetasyon türlerine bakıldığında alanın $\% 45,7$ 'sinin, riskli ve yüksek riskli seviyede olduğu gözlemlenmektedir. Bölgenin \%9,7'sini risksiz düzlükler, \%26,3'lük kısmını yüksek riskli güney yamaçlar kaplamaktadır. Literatür ile uyumlu olarak yola ve yerleşim yerlerine yakınlığın yangın riskini arttırdığı görülmüştür. Menteșe yöresinde büyük oranda yayılmıș ve risk olușturabilecek yerleșmeler çalıșma alanının $\% 60,2$ 'sini kapsamaktadır.

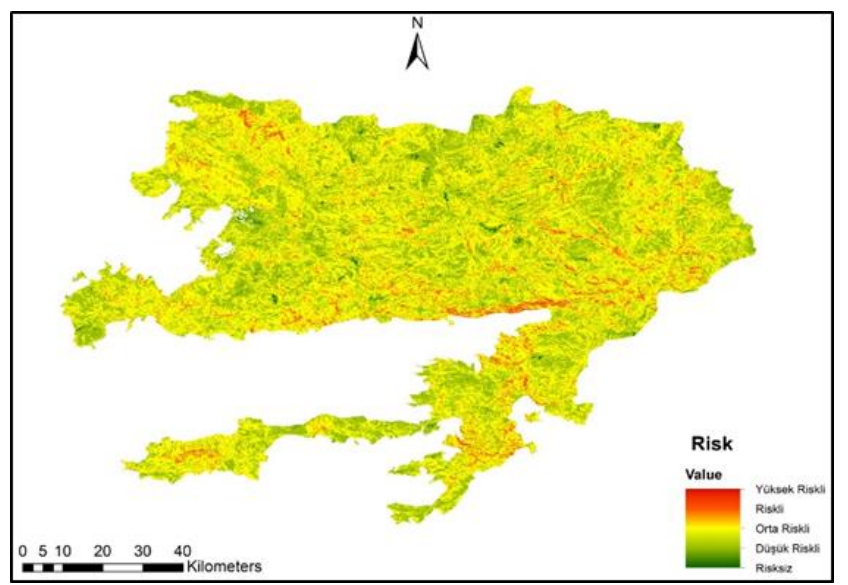

Şekil 11. Muğla ile Menteşe yöresi orman yangını risk haritası

Tüm değerlendirme ve analizler sonucunda Muğla ili Menteșe yöresinin orman yangını risk haritası hazırlanmış ve Şekil 11'da verilmiştir. Yangın duyarlılık sınıflarının alansal dağılımı ise Raster verilerinin vektör veriye dönüștürülmesi sonucu oluşturulmuştur. Kontrollü sınıflandırmada tarım, yerleşim ve ormanlık alanlar gibi tüm alanlar sınıflandırıldığından verilen yüzdeler toplam alan üzerinden hesaplanmıștır. Hazırlanan yangın risk haritasında çalıșma alanın $\% 11,86$ yüksek riskli, $\% 18,32$ riskli, $\% 25,23$ orta riskli, $\% 20,40$ düşük riskli ve \%24,19 ise risksiz olarak belirlenmiştir.

İnsan-orman etkileşiminin fazla olması orman yangılarının başlıca sebepleri arasında gösterilmektedir (Bingöl 2017). Kızılçam ve karaçam gibi yanma potansiyeli yüksek ormanlarının varlığı ve yerleşimlerin yoğun bir șekilde görülmesi yangın risk haritalanın önemli faktörleridir (Karabulut vd. 2013). Muğla ili Menteșe ilçesi kıyı şeridi ile Milas ilçesi; eğim, bakı, yola mesafe ve kızılçam ormanları nedeniyle çalışma alanında en riskli bölgelerdir. Çalışma alanında genel olarak tarım arazilerinin yoğun, eğimin az olduğu bölgelerin düşük riskli olduğu görülmektedir. Kızılçam ormanlarına ve güney bakıya sahip alanlarda yangın potansiyelinin daha fazla olduğu gözlemlenmektedir.

Tablo 2. Vejetasyon türleri risk sınıflandırma haritası

\begin{tabular}{ccccccc}
\hline Faktör & Risk Seviyesi & $\begin{array}{c}\text { Bitki örtüsü } \\
\text { Alan (\%) }\end{array}$ & $\begin{array}{c}\text { Ĕ̈im } \\
\text { Alan (\%) }\end{array}$ & $\begin{array}{c}\text { Bakı } \\
\text { Alan (\%) }\end{array}$ & $\begin{array}{c}\text { Yola uzaklık } \\
\text { Alan (\%) }\end{array}$ & $\begin{array}{c}\text { Yerleşmeye uzaklık } \\
\text { Alan (\%) }\end{array}$ \\
\hline 5 & Yüksek Riskli & $\% 15,2$ & $\% 2,9$ & $\% 26,3$ & $\% 6,1$ & $\% 0,7$ \\
4 & Riskli & $\% 30,5$ & $\% 11,0$ & $\% 21,2$ & $\% 5,8$ & $\% 9,8$ \\
3 & Orta Riskli & $\% 34,8$ & $\% 26,1$ & $\% 23,0$ & $\% 6,2$ & $\% 24,2$ \\
2 & Düşük Riskli & $\% 17,5$ & $\% 31,3$ & $\% 19,8$ & $\% 4,9$ & $\% 25,5$ \\
1 & Risksiz & $\% 2,0$ & $\% 28,7$ & $\% 9,7$ & $\% 77,0$ & $\% 39,8$ \\
\hline
\end{tabular}

\section{SONUÇLAR}

Yangınlar dünya çapında ormanların büyük kısmını yok etmektedir. Kayıtlı orman yangını istatistiklerine göre, 1937-2003 yılları arasında ülkemizde yaklaşık 1.6 milyar hektar orman yanmış, 2020 yılı itibariyle bu değer yaklaşık 1.8 milyar hektara çıkmıştır. Ayrıca yangınlar belirli bölgelerde tekrarlanabilmektedir (Ertuğrul 2005). Tüm bu veriler, orman yangını risk haritalarının hazırlanması ve orman yangın yönetimi modellerinin geliştirilmesini gerekliliğini göstermektedir. Bu çalışma, riskli yerleri belirlemek ve ormancılık yönetiminin planlaması için çevresel faktörleri ve CBS konseptini kullanmayı amaçlamaktadır. Yangın risk modelleri, ormanların korunmasına yönelik ihtiyati tedbirler için gerekli bir yaklaşımdır.

Orman yangın yönetiminin bir parçası olan orman yangını risk haritası 2018 yılında Türkiye'de en çok 
orman yangınının görüldüğü Muğla-Menteşe yöresi için CBS ortamında hazırlanmıştır. Bu harita ile orman yangını yayılımına karşı önleme faaliyetleri bölge bazında farklılaştırılabilecektir. Böylece daha etkili yönetim modelleri uygulanabileceği gibi, optimum kaynak kullanımı vb. ekonomik avantajlar elde edilebilecektir.

Sonuçların Başaran vd. 2004 tarafından önerilen yeni kurulacak ormanların yangına dirençli hale getirilmesi ve ilk müdahale süresini kısaltmaya yönelik öneriler kapsamında da fayda sağlayacağı düşünülmektedir. Calıșmada, sabit çevre faktörlerinin yangın riski üzerindeki etkisi değerlendirilmiştir. Model değişkenleri bitki örtüsü, eğim, bakı, yola ve yerleşmeye olan mesafedir. Her değişken için uygun ağırlık değişkenleri seçilmiştir ve modelin çıktısı çalışma alanının özelliklerine göre ayarlamaya çalışılmıştır. Orman risk bölgesi haritalaması için Erten vd. (2005) ve Joaquim vd. (2007) tarafından belirlenen ağırlıklar kullanmıştır. Yangın söndürme planının daha etkili olabilmesi için modelde değişken çevre parametrelerinin de (sıcaklık, nispi nem, rüzgâr hızı) analiz edilmesi önerilmektedir.

\section{ARAŞTIRMACILARIN KATKI ORANI}

Mehmet Hanifi Alkayış: Modelleme, Makale yazma, Asena Karslıoğlu: Araştırma, Makale yazma, Mehmet İnanç Onur: Düzenleme

\section{ÇATIŞMA BEYANI}

Herhangi bir çıkar çatışması bulunmamaktadır.

\section{KAYNAKÇA}

Akbulak C, Tatlı H, Aygün G \& Sağlam B (2018). Forest fire risk analysis via integration of GIS, RS and AHP: The Case of Çanakkale, Turkey. Journal of Human Sciences, 15(4), 2127-2143.

Akkaş M E, Bucak C, Boza Z, Eronat H, Bekereci A, Erkan A, Cebeci C (2008). Büyük Orman Yangınlarının Meteorolojik Veriler Işı̆̆ında İncelenmesi, T.C. Çevre ve Orman Bakanlığı Ege Ormancilık Araştırma Müdürlüğü, Yayın No:333, Müdürlük Yayın No: 048.

Asri İ, Çorumluoğlu Ö \& Özdemir E (2015). CBS destekli orman yangını risk dagılım analizi; Antalya örneği, Türkiye Harita Bilimsel ve Teknik Kurultayı.

Avila-Flores D, Pompa-Garcia M, Antonio-Nemiga X, Rodriguez-Trejo D., Vargas-Perez E., Santillan-Perez J. (2010). Driving factors for forest fire occurrence in Durango State of Mexico: a geospatial perspective. Chin Geograph Sci 20(6):491-497. doi:10.1007/s11769-010-0437-x

Başaran M A, Sarıbaşak H \& Cengiz Y (2004). Yangın söndürme planı temel esaslarının belirlenmesi
(Manavgat örneği). Çevre ve Orman Bakanlı̆̆ı Batı Akdeniz Ormancılık Araştırma Müdürlüğü.

Bingöl B (2017). Determination of Forest Fire Risk Areas in Burdur Province Using Geographical Information Systems. Turkish Journal Of Forest Science, 1(2), 169182.

Eron Z (1988). Orman Yangınları Ve Mücadele Yöntemleri, Ormancılık Araştırma Enstitüsü Yayınları, Muhtelif Yayınlar Serisi, 5-6 Ekim 1988, Ankara.

Erten E, Kurgun V \& Musaoğlu N (2005). Uzaktan algılama ve CBS kullanarak orman yangını bilgi sisteminin kurulması, TMMOB Harita ve Kadastro Mühendisleri Odası 10. Türkiye Harita Bilimsel ve Teknik Kurultayı-2005, Ankara.

Ertuğrul M (2005). Orman Yangınlarının Dünyadaki Ve Türkiye'deki Durumu. Bartın Orman Fakültesi Dergisi, 7(7), 43-50.

Jaiswal R K, Mukherjee S, Raju K D \& Saxena R (2002). Forest fire risk zone mapping from satellite imagery and GIS. International Journal of Applied Earth Observation and Geoinformation, 4(1), 1-10.

Joaquim G, Bahaaeddın A \& Josep R (2007). Remote Sensing Analysis to Detect Fire Risk Locations, Canada.

Karabulut M, Karakoç A, Gürbüz M, Kızılelma Y (2013). Coğrafi bilgi sistemleri kullanarak başkonuş dağında (Kahramanmaraş) orman yangını risk alanlarının belirlenmesi, Uluslararası Sosyal Araştırmalar Dergisi, Cilt: 6, Sayı: 24.

Sharma D, Hoa V, Cuong T V, Tuyen T \& Sharma N (2009, October). Forest fire risk zonation for Jammu district forest division using remote sensing and GIS. In 7th FIG Regional Conference, Spatial Data Serving People: Land Governance and the Environment-Building the Capacity. Hanoi, Vietnam (pp. 19-22).

Sharples J, McRae R, Weber R, Gill A (2009). A simple index for assessing fire danger rating. Environmental Modelling and Software, 24(6): 764-774.

Türkeş M \& Altan G (2013). İklimsel Değişimlerin ve Orman Yangınlarının Muğla Yöresi'ndeki Doğal Çevre, Doğa Koruma Alanları ve Biyotaya Etkilerinin bir Ekolojik Biyocoğrafya Çözümlemesi. Ege Coğrafya Dergisi, 22(2), 57-75.

URL-1, Tarım ve Orman Bakanlığı, Meteoroloji Genel Müdürlüğü, https://www.mgm.gov.tr, [Erişim 2018]

URL-2, Tarım ve Orman Bakanlığl, Orman Genel Müdürlüğü,https://www.ogm.gov.tr/ekutuphane/Sa yfalar/Istatistikler.aspx [Erişim 28 Haziran 2019]

URL-3, Tarım ve Orman Bakanlığı, Orman Genel Müdürlüğü, Muğla Orman Bölge Müdürlüğü, https://muglaobm.ogm.gov.tr [Erişim 2018]

WRI, Dünya Kaynakları Enstitüsü, https://www.wri.org/, [Erişim 2019] 